\title{
The Impact of Nutrient and Heavy Metal Concentrations on Waste Dump Soils in Mangrove and Non-mangrove Forest in the Niger Delta, Nigeria
}

\author{
Aroloye Ofo Numbere \\ Department of Animal and Environmental Biology, University of Port Harcourt, Choba, Nigeria \\ Email address: \\ aroloyen@yahoo.com \\ To cite this article: \\ Aroloye Ofo Numbere. The Impact of Nutrient and Heavy Metal Concentrations on Waste Dump Soils in Mangrove and Non-mangrove \\ Forest in the Niger Delta, Nigeria. Journal of Energy and Natural Resources. Vol. 8, No. 3, 2019, pp. 109-115. \\ doi: $10.11648 /$ j.jenr.20190803.12
}

Received: July 18, 2019; Accepted: August 13, 2019; Published: August 23, 2019

\begin{abstract}
This study is based on the comparison of nutrient and heavy metal concentrations in soils from waste dump sites in mangrove and Non-mangrove forest i.e. municipal areas. Nine soil samples were collected randomly at three sites in each location with soil auger, $5 \mathrm{~cm}$ below the top soil $(\mathrm{n}=18)$. The soils were placed in polyethylene bags and sent to the laboratory for physicochemical analysis for nutrients: Calcium (Ca), Potassium (K), Magnesium (Mg), Manganese (Mn), Phosphorus (P) and Sulphate $\left(\mathrm{SO}_{4}\right)$ and heavy metals: Zinc $(\mathrm{Zn})$, Lead $(\mathrm{Pb})$, Copper $(\mathrm{Cu})$, and Cadmium $(\mathrm{Cd})$ concentrations. The metals were measured by UV/visible spectrophotometric method using HACH DR 890 colorimeter (wavelength $\sim 420 \mathrm{~nm}$ ). The result indicates that there was no significant difference in heavy metal concentration between mangrove and Non-mangrove soils $\left(\mathrm{F}_{1,58}\right.$ $=0.24, \mathrm{P}>0.05)$. However, heavy metals were higher in non-mangrove than in mangrove soil. Zinc had the highest overall concentration $(37.9 \pm 6.7 \mathrm{mg} / \mathrm{l})$ followed by $\mathrm{Pb}(12.7 \pm 3.1 \mathrm{mg} / \mathrm{l})$ and $\mathrm{Cu}(10.0 \pm 1.4 \mathrm{mg} / \mathrm{l})$ in non-mangrove soil, whereas $\mathrm{Cd} \mathrm{was}$ ten times higher in mangrove $(0.4 \pm 0.2 \mathrm{mg} / \mathrm{l})$ than in non-mangrove $(0.04 \pm 0.03 \mathrm{mg} / \mathrm{l})$ soil. The order of heavy metal concentration in mangrove soil is $\mathrm{Zn}>\mathrm{Pb}>\mathrm{Cu}>\mathrm{Cd}$ and in non-mangrove soil is $\mathrm{Zn}>\mathrm{Cu}>\mathrm{Pb}>\mathrm{Cd}$. In contrast, there was a significant difference in nutrient concentration between mangrove and non-mangrove soils $\left(\mathrm{F}_{1,88}=4.39, \mathrm{P}<0.05\right)$. Similarly, nutrient elements $(\mathrm{Ca}$, $\mathrm{K}$, $\mathrm{Mg}, \mathrm{Mn}$ and $\mathrm{P}$ ) were higher in non-mangrove soil than mangrove soils while $\mathrm{SO}_{4}$ was higher in mangrove than in non-mangrove soil, The order of nutrient concentration in mangrove soil is $\mathrm{Ca}>\mathrm{Mg}>\mathrm{K}>\mathrm{SO}_{4}>\mathrm{Mn}>\mathrm{P}$ and in non-mangrove soil is $\mathrm{Ca}>\mathrm{Mg}>\mathrm{K}>\mathrm{Mn}>\mathrm{SO}_{4}>\mathrm{P}$. There was a slight a positive correlation between the nutrient and heavy metal concentration $\left(\mathrm{R}^{2}=0.016\right.$, $\mathrm{n}=90, \mathrm{P}=0.001)$. Results show that municipal soil is more polluted with industrial waste than mangrove forest soil as a result of high anthropogenic activities. Thus harmful metals from mangrove and Non-mangrove soils can enter the food chain and drinking water source leading to adverse health effect.
\end{abstract}

Keywords: Mangrove, Heavy Metals, Waste Dump, Nutrients, Rhizophora, Soil

\section{Introduction}

Waste is a material that is no longer useful to the production system [1], but useful to another process. Mangroves are a set of herbaceous plant that grows singly as individual trees or in communities in wet land region [2]. Mangroves are habitat specialist and do not grow outside the coastal environment. They are halophilic, and can survive in highly saline environment [3]. They reduce the intake of excess salt into their system in three ways: (1) by shutting off the intake of excess salt through their root; (2) exudation of salt crystals from their leaves, and (3) storage and expulsion of salt through senescent leaves [4]. The growth of mangrove in wetland areas predisposes them to anthropogenic action of waste disposal. Since mangroves are found in the interface between the land and the sea they easily become recipients of waste disposed on land or in water. Mangroves are affected by chemical contamination from upland run off during erosion from heavy down pour [5]. Heavy metals from industrial activities (Drink Company, food industry, paint industry, oil and gas industries etc), which originate from municipal areas migrate via flooding and erosion to wetland areas. Mangroves are also 
affected by tidal currents, which wash ashore waste materials that are carried from other locations. The effects of heavy metal on mangroves have been studied by other researchers [6] Damage of mangrove resulting from wastes disposal, may compromise its ability to retain nutrients. This was confirmed at severely damaged mangrove sites in North Queensland, Australia where significant loss of both nitrogen and phosphorus from the soils were recorded [7]. Mangrove ecosystem acts as a buffer between near shore and lagoon or estuarine environments with regard to the influence of freshwater discharge and salinity regime [8]. The quality of water is dependent on a number of physico-chemical parameters and the magnitude and source of pollution load. Therefore, the monitoring of these parameters are essential [9]. The mangrove system plays a major role in the global cycle of carbon, nitrogen as well as sulphur, and acts as reservoirs of waste materials [6]. A few authors have studied the physical and chemical characteristics of some Indian estuaries and mangroves [10, 11].

The encroachment of humans into mangrove forest leads to the accumulation of waste products in the forest. This accumulation impact the health of the mangroves by contaminating the soil and increasing the presence of toxic metals [12]. Mangroves are sensitive to changes in soil quality, which affects their growth and productivity [13]. This can lead to negative bio-stimulation and death of the plants. Poor waste management practices and lack of provision of waste disposal facilities had made residents of coastal communities to throw their waste directly into the sea or in open dumps near mangrove forests [14]. The waste product remains under the element of the weather to decompose and percolate into the ground water aquifer. Decomposition of the waste products can affect the mangrove ecosystem and people living around the area when toxic elements enter the food chain. Leachate from waste dump sites percolate into surface and ground water to cause further contamination. A comparison of the distribution of heavy metals (e.g. Hg and $\mathrm{Zn}$ ) in sediments of a degraded area, with those under mangroves at the Gramacho landfill shows that the metal distribution profiles along sediment cores from the degraded area suggest remobilization and export of heavy metals from the sediments [15]. Under mangroves, much larger metal concentrations were retained around the rhizosphere layer, and within the sediments, thus hampering their migration. This is seen from the sharp decrease in metal concentration at the top layers of the sediment, and their export to adjacent coastal waters. Specialized studies showed that these heavy metals are present in the rhizosphere sediments under very refractory chemical forms, unable to be absorbed by plant roots, which blocks intoxication of the mangrove [15]. Mangroves help to minimize pollution in the environment by absorbing pollutants. They also reduce global warming by being the highest atmospheric carbon dioxide sequesters. However, Excess nutrients especially phosphates, sulphates and nitrates are classified as pollutants in waste water. Large tonnage of phosphate enters rivers and lakes through super phosphate fertilizer washed from soil and from chemicals used to improve the performance of detergents [16]. Phosphate is considered a pollutant principally because of lake eutrophication [16]. Heavy metal concentrations in soils are associated with biological and geochemical cycles and are influenced by anthropogenic activities such as agricultural practices, industrial activities and waste disposal methods. Nutrient enrichment in mangrove soil is caused by effluent and aquaculture waste water [17].

Zinc is used to galvanize other metals such as iron to prevent rusting. Galvanized steel is used for car bodies and street lamps posts that are found in Non-mangrove areas. Zinc is also used in alloys such as brass; nickel, silver and aluminum solder. High $\mathrm{Zn}$ concentration had been reported in mangrove organisms such as fishes and crabs (Goniopsis pelii) in the Niger Delta area.

In other to determine the physico-chemistry of soils in waste dump sites in mangrove and Non-mangrove forest a comparative study between the nutrient and heavy metal load was done. The Non-mangrove location was used as the control experiment. The objectives of the study therefore, are: (1) to determine the nutrient content in mangrove and non-mangrove forest soils; (2) to determine the heavy metal concentration in mangrove and non-mangrove forest soils; (3) to compare the nutrient and heavy metal concentration of mangrove and Non-mangrove forest soils.

\section{Material and Methods}

\subsection{Description of Study Area}

The study area is located in the Niger Delta (Figure 1). It is a tropical region with high rain fall occurring all throughout the year i.e. from January to December. There are two major seasons, the dry and the wet seasons, which occur between November to March and March to October, respectively [18]. The area has a mean precipitation of $1240 \mathrm{~mm}$. The major wetland species is the mangroves (Rhizophora species). The mangrove soil is swampy and ranges from brown to black in color while upland soil is hard and coffee brown in color. The $\mathrm{pH}$ of the soil ranges from 6.5-7.0 for the mangrove forest soil while for the non-mangrove forest soil the $\mathrm{pH}$ ranges from $7.0-8.6$.

The mangrove forest dump sites situated in three communities namely: (1) Buguma $\left(4^{\circ} 45^{\prime} \mathrm{N}, 6^{\circ} 56^{\prime} \mathrm{E}\right)$ (2) Okrika Jetty $\left(4^{\circ} 43^{\prime} \mathrm{N}, 7^{\circ} 05^{\prime} \mathrm{E}\right)$, and (3) Eagle Island $\left(4^{\circ} 47^{\prime} \mathrm{N}\right.$, $\left.7^{\circ} 58^{\prime} \mathrm{E}\right)$. Buguma dump site is a mangrove forest at the foot of a small bridge linking Abiama. The type of waste found is mainly plastic (water proof, plastic bottled water, basin, etc), paper (newspaper, food packaging) and clothing (dress, clothes, rags) products. Okrika sample site is close to a jetty where crude oil is evacuated to foreign countries. The dump site is located near a mangrove forest. The waste is mainly made up of plastic materials such as discarded bottled water containers, water proof, paper, metal parts, etc.

The non-mangrove forest locations are situated in the municipal areas around the capital city of Port Harcourt (Table 1). These areas are the control and their soil physico-chemistry 
is used to compare with that of the mangrove forest areas. The three study locations are university campuses namely:
University of Port Harcourt (UPH), Rivers State University (RSU) and the Ignatius Ajuru University (IAU).

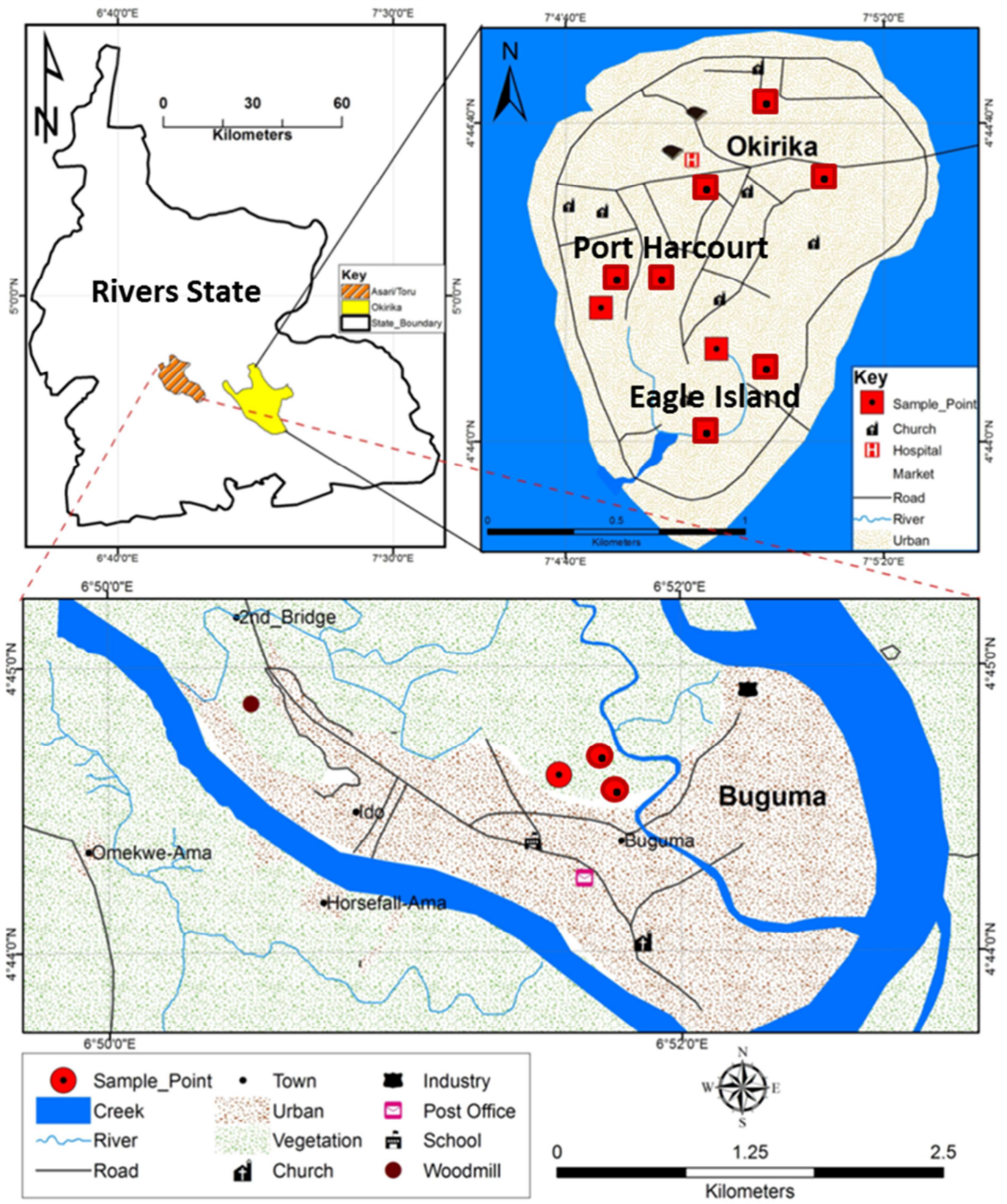

Figure 1. Map of study areas showing places of soil sample collection in mangrove and non-mangrove forest sites in the Niger Delta, Nigeria.

Table 1. Coordinates of waste dump sites situated in non-mangrove forest areas in the Niger Delta.

\begin{tabular}{lllllll}
\hline \multirow{2}{*}{ SITES } & UNIPORT & & RSU & IAU & Elevation \\
\cline { 2 - 7 } & Dump site & Elevation & Dump site & Elevation & Dump site & N458.357 E656.132 \\
\hline 1 & N454.270 E655.303 & $10.0 \mathrm{~m}$ & N447.328 E658.936 & $12.0 \mathrm{~m}$ & $\mathrm{~m}$ \\
2 & N454.103 E658.936 & $13.0 \mathrm{~m}$ & N447.314 E658.936 & $9.0 \mathrm{~m}$ & N448.230 E655.998 & $6.0 \mathrm{~m}$ \\
3 & N454.018 E655.466 & $8.0 \mathrm{~m}$ & N447.920 E658.699 & $8.0 \mathrm{~m}$ & N448.357 E655.900 & $6.0 \mathrm{~m}$ \\
\hline
\end{tabular}

\subsection{Experimental Design}

In each location three sites were selected and soil samples collected. The experiment is a randomized complete block design $(3 \times 3 \times 3)$ for mangrove and non-mangrove locations $(\mathrm{n}$ $=9)$.
Sample Collection and Physicochemical Analysis

Nine soil samples were collected from each location (Figure 2) with a hand held soil augur (Germany) $5 \mathrm{~cm}$ below the soil surface. Soil samples collected were placed in black cellophane bags, placed in a cooler and sent to the laboratory for physicochemical analysis following standard methods [19]. 
For Both the mangrove and non-mangrove forest soil samples, the physicochemical parameters that were determined in the laboratory were four heavy metals namely Cadmium (Cd), Copper (Cu), Zinc ( $\mathrm{Zn})$, Lead $(\mathrm{Pb})$ and Zinc $(\mathrm{Zn})$ and six nutrient elements namely Calcium (Ca), Magnesium (Mg), Manganese (Mn), Phosphorous (P), Potassium (k), and Sulphate $\left(\mathrm{SO}_{4}\right)$ following standard methods [19]. The metals were measured by UV/visible spectrophotometric method using HACH DR 890 colorimeter (wavelength 420nm) [20].

\subsection{Statistical Analysis}

An analysis of variance (ANOVA) was conducted to determine whether there was a significant difference in nutrient and heavy metal concentration between mangrove and Non-mangrove soils [21]. Box plots were done to test normality and homoscedasticity, after which logarithmic transformation was done. Pearson's product-moment correlation was done to test whether there was relationship between nutrient and heavy metal concentration in mangrove and Non-mangrove forest soils [22]. Bar graphs were used to illustrate the differences in concentration between the mangrove and Non-mangrove forest soils. All analyses were done in [23].

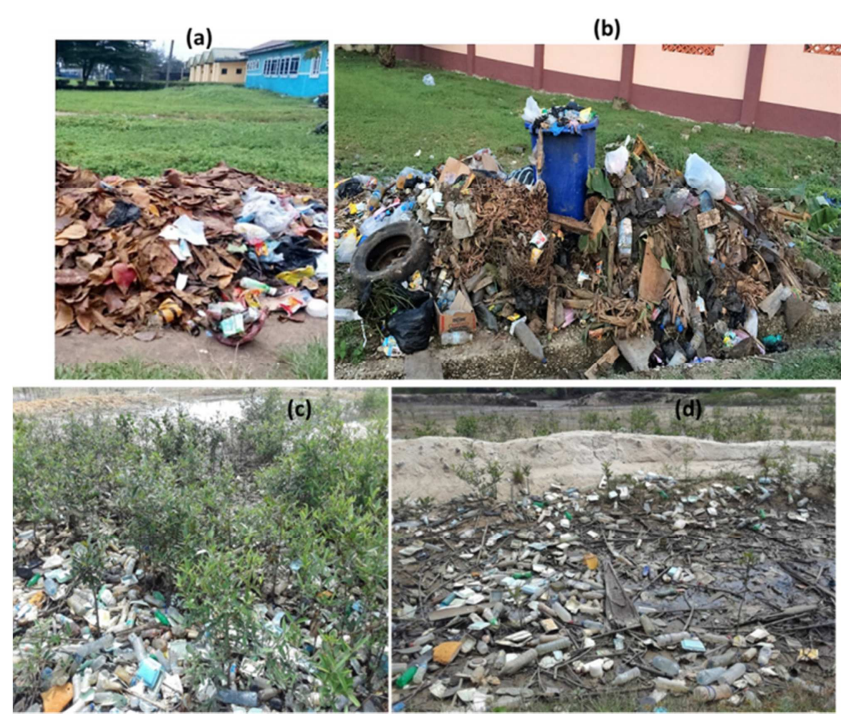

Figure 2. Waste dump sites at non-mangrove (a and b) (university campuses) and mangrove ( $c$ and d) forests in the Niger Delta, Nigeria. Three soil samples each were collected at each geo-referenced site in mangrove and non-mangrove forests.

\section{Results}

\subsection{Heavy Metal Concentrations in Mangrove and Non-mangrove Forest}

The result (Figure 3) indicates that there is no significant difference in heavy metal concentration between mangrove and non-mangrove forest soils $\left(\mathrm{F}_{1,}{ }_{58}=0.24, \mathrm{P}>0.05\right)$. However, heavy metals were higher in non-mangrove than mangrove soil (Table 2). Zinc had the highest overall concentration $(37.9 \pm 6.7 \mathrm{mg} / \mathrm{l})$ followed by $\mathrm{Pb}(12.7 \pm 3.1$ $\mathrm{mg} / \mathrm{l})$ and $\mathrm{Cu}(10.0 \pm 1.4 \mathrm{mg} / \mathrm{l})$ in non-mangrove soil, whereas only cadmium was higher in mangrove $(0.4 \pm 0.2 \mathrm{mg} / \mathrm{l})$ than in non-mangrove soil $(0.04 \pm 0.03 \mathrm{mg} / \mathrm{l})$. The level of $\mathrm{Cd}$ in mangrove soil is 10 times more than that of Non-mangrove soil (Table 2). The order of heavy metal concentration in mangrove soil is $\mathrm{Zn}>\mathrm{Pb}>\mathrm{Cu}>\mathrm{Cd}$ and in non-mangrove soil is $\mathrm{Zn}>\mathrm{Cu}>\mathrm{Pb}>\mathrm{Cd}$.

Table 2. Mean levels of heavy metals \pm 1 SE between mangrove ( $R$. racemosa) and non-mangrove forest soils in the Niger Delta, Nigeria.

\begin{tabular}{lllll}
\hline \multirow{2}{*}{ Forest types } & \multicolumn{4}{l}{ Metals mg/l } \\
\cline { 2 - 5 } & $\mathbf{C d}$ & $\mathbf{C u}$ & $\mathbf{P b}$ & $\mathbf{Z n}$ \\
\hline Mangrove & $0.4 \pm 0.2^{\mathrm{a}}$ & $9.9 \pm 6.6^{\mathrm{a}}$ & $8.0 \pm 4.2^{\mathrm{a}}$ & $31.6 \pm 17.3^{\mathrm{a}}$ \\
Non-mangrove & $0.04 \pm 0.03^{\mathrm{b}}$ & $10.0 \pm 1.4^{\mathrm{a}}$ & $12.7 \pm 3.1^{\mathrm{a}}$ & $37.9 \pm 6.7^{\mathrm{a}}$ \\
\hline
\end{tabular}

Different letters on column indicate significant differences $(\mathrm{P}<0.05)$.

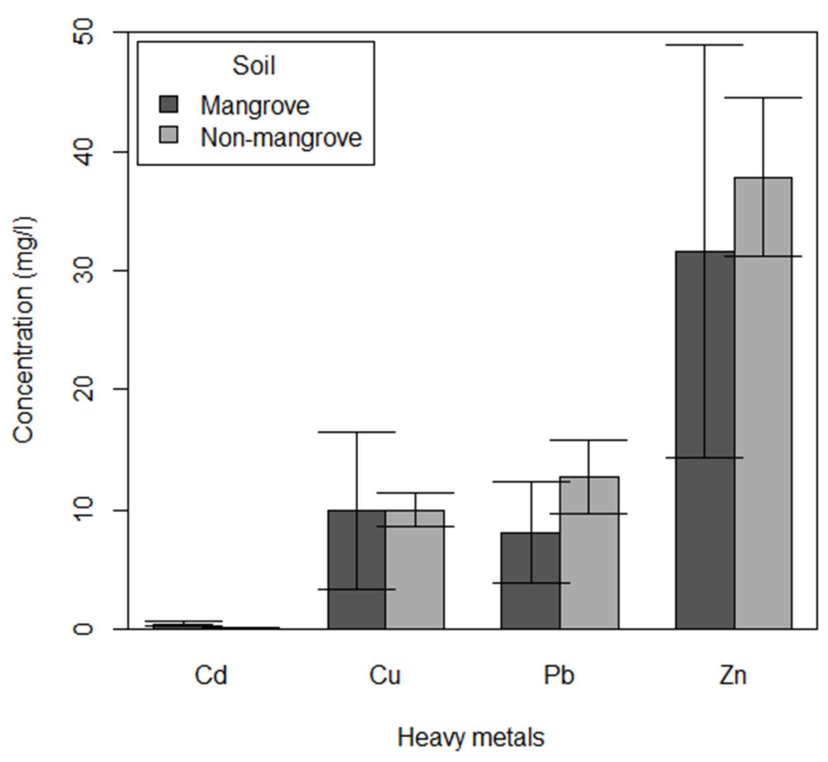

Figure 3. Graph of concentration of heavy metals in mangrove and nonmangrove forest soils in the Niger Delta. There was no significant difference in heavy metal concentration between mangrove and non-mangrove soils $\left(F_{1,58}=0.24, P>0.05\right)$. However, heavy metal was higher in non-mangrove soil.

\subsection{Nutrient Concentration in Mangrove and Non-mangrove Forest}

The result (Figure 4) indicates that there is a significant difference in nutrient concentration between mangrove and non-mangrove forest soils $\left(\mathrm{F}_{1,88}=4.39, \mathrm{P}<0.05\right)$. Nutrient elements were higher in non-mangrove than mangrove soils in $\mathrm{Ca}, \mathrm{K}, \mathrm{Mg}, \mathrm{Mn}$ and $\mathrm{P}$ while $\mathrm{SO}_{4}$ was higher in mangrove than in non-mangrove soil (Table 3). Sulphate concentration is 2.6 times more in mangrove than in Non-mangrove soil (Table 3). However, the Tukey test revealed that at alpha $=$ 0.05 the most significant point lies between the following four nutrients groupings: $\mathrm{SO}_{4}-\mathrm{Ca}, \mathrm{P}-\mathrm{Ca}, \mathrm{Mn}-\mathrm{Ca}$ and $\mathrm{K}-\mathrm{Ca}$. This indicates that $\mathrm{Ca}$ had the highest concentration for both mangrove and non-mangrove soils, followed by $\mathrm{Mg}$ and $\mathrm{K}$. The order of heavy nutrient concentration in mangrove soil is $\mathrm{Ca}>\mathrm{Mg}>\mathrm{K}>\mathrm{SO}_{4}>\mathrm{Mn}>\mathrm{P}$ and in nonmangrove soil is $\mathrm{Ca}>\mathrm{Mg}>\mathrm{K}>\mathrm{Mn}>\mathrm{SO}_{4}>\mathrm{P}$. 
Table 3. Mean levels of nutrient elements \pm 1 SE between mangrove (R. racemosa) and non-mangrove (university campuses) forest soils in the Niger Delta, Nigeria.

\begin{tabular}{lllllll}
\hline Forest types & \multicolumn{5}{c}{ Nutrient (mg/l) } \\
\hline & $\mathbf{C a}$ & $\mathbf{K}$ & $\mathbf{M g}$ & $\mathbf{M n}$ & $\mathbf{P}$ & $\mathbf{S O}_{4}$ \\
\hline Mangrove & $450.6 \pm 225.3^{\mathrm{b}}$ & $187.7 \pm 61.6^{\mathrm{a}}$ & $522.2 \pm 113.5^{\mathrm{a}}$ & $21.0 \pm 11.6^{\mathrm{b}}$ & $0.11 \pm 0.03^{\mathrm{b}}$ & $64.3 \pm 35.7^{\mathrm{a}}$ \\
Non-mangrove & $1661.4 \pm 69.8^{\mathrm{a}}$ & $380.9 \pm 220.8^{\mathrm{a}}$ & $571.0 \pm 96.8^{\mathrm{a}}$ & $83.8 \pm 17.6^{\mathrm{a}}$ & $0.6 \pm 0.2^{\mathrm{a}}$ & $24.6 \pm 6.9^{\mathrm{b}}$ \\
\hline
\end{tabular}

Different letters on column indicate significant differences $(\mathrm{P}<0.05)$.

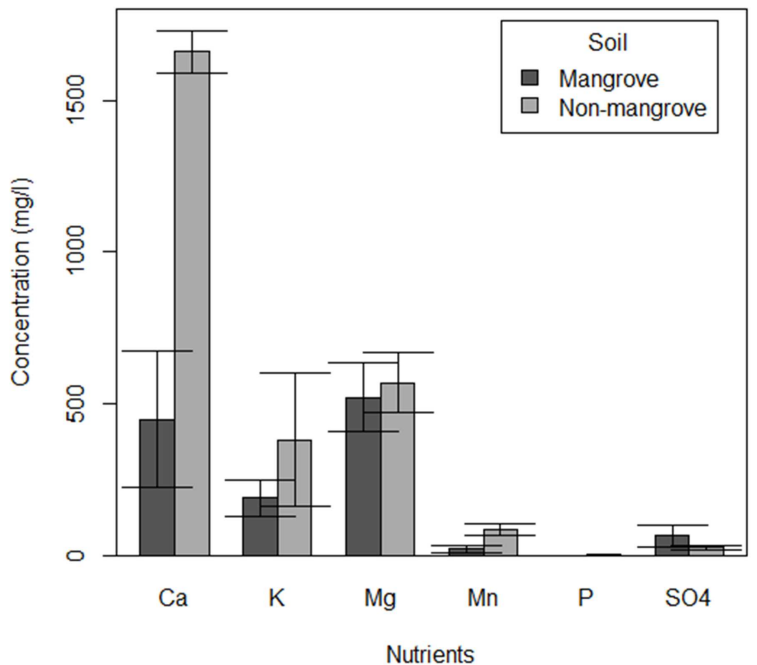

Figure 4. Graph of concentration of nutrient elements in mangrove and nonmangrove forest in the Niger Delta. There was significant difference in nutrient concentration between mangrove and non-mangrove soils $\left(F_{1,88}=\right.$ 4.39, $P<0.05)$. Nutrient element was higher in non-mangrove soil than mangrove soils.

\subsection{Nutrient and Heavy Metal Relationship in Mangrove and Non-mangrove Forests}

The results indicate that there was significant difference in nutrient and heavy metal concentrations in mangrove and Non-mangrove forest soils $(\mathrm{P}<0.001)$. There was also a positive correlation between the nutrient and heavy metal concentrations $\left(\mathrm{R}^{2}=0.016, \mathrm{n}=90, \mathrm{P}=0.001\right)$. This means that as the heavy metal increase the nutrient concentration also increase (Figure 5).

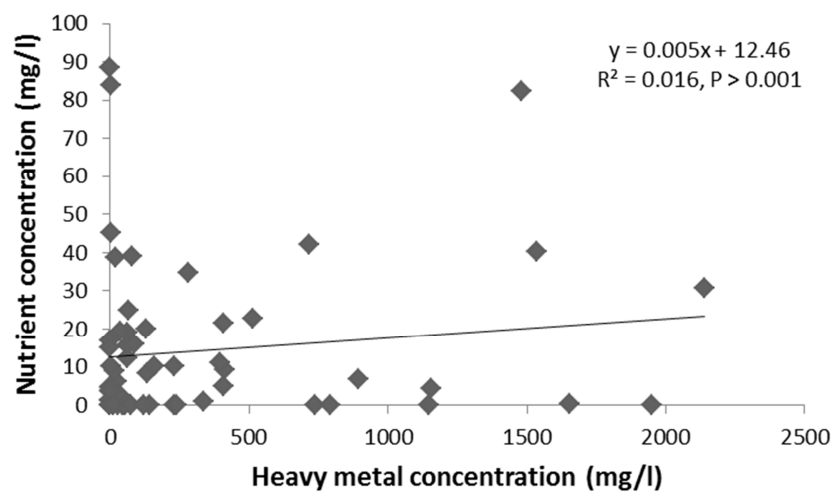

Figure 5. Correlation graph of nutrient and heavy metal concentration in mangrove and non-mangrove forest soil in the Niger Delta, Nigeria. It indicates a positive relationship, which means as the heavy metal concentration increase the nutrient level increase.

\section{Discussion}

\subsection{Heavy Metal Concentration in Mangrove and Non-mangrove Forest}

Heavy metal concentration in mangrove and non-mangrove soils did not differ significantly, which is in line with the result of [24], who found no difference in heavy metal concentration between sediments from mangroves developing upstream and downstream of urban areas. [24] further explained that there is migration of heavy metals from upstream to downstream locations. The geochemistry of mangrove and Non-mangrove soil is not the same, but due to the migration of metals from upstream to downstream the concentration has become closer. However, heavy metals were relatively higher in Non-mangrove soils in this study because it is mainly situated in municipal areas that are recipients of industrial depositions such as electronic, market, household and office waste (Figures 3 and 4) [12]. The numbers of waste dump sites situated in Non-mangrove areas are more than in mangrove forest areas. The main system of waste disposal in municipal areas is open dump. The waste is either deposited on concrete floors or on the soil. The waste on the concrete dissolves and its liquid migrate to the soil while liquid from the waste dumped on the soil percolate deep down the soil profile into ground water. The long residence time of the wastes at the dump sites (i.e. 1-14 days) subject them to weather effects of heavy rain fall and intense sunlight. The waste gets soaked by water during rainfall and also becomes liquefied by the heat of the sun. The waste water is then carried by flooded water into rivers or percolates deep down the soil profile into ground water. Based on this analysis it shows that the movement of heavy metal is from Non-mangrove to mangrove forest. Mangroves act as buffer zone for waste water flowing from the municipal areas. There is thus a decrease in heavy metal concentration from the municipality to the forest areas as shown in Table 2 and Figure 4. However, the situation is different for Cadmium, which has a higher concentration in mangrove forest than in Non-mangrove forest. This is because Cadmium is a major component of crude oil pipelines, which runs across the mangrove forest at Okrika, the host of a major refinery, where the soil samples were collected.. Corrosion of the pipes is facilitated by its exposure to saline water in the environment, which carries the metal-laden water into the mangrove forest. In the same vein, crude oil spillages occur at offshore and onshore locations. Crude oil spillages occur from punctured crude oil pipelines and faulty well heads situated within the mangrove forest as a result of sabotage, mechanical failure and old age [25]. Crude oil activities are non-existent on 
municipal areas such as campuses where the soil samples for Non-mangrove areas were collected. There was high concentration of Zinc in Non-mangrove areas because it comes from both household and industrial sources. Some industrial waste include metal parts like corrugated roofing sheet, automobile parts, electrical and hardware components, which are mainly found within the city limits (i.e. non-mangrove areas) [26].

\subsection{Nutrient Concentration in Mangrove and Non-mangrove Forests}

Nutrient concentration was higher in non-mangrove forest than in mangrove forest because municipal areas have more industries such as culinary, confectionary and drink industries that utilize organic products (e.g. sugars and sweeteners) as raw materials for their manufacturing process. Due to poor waste management practice by these companies, the waste generated is disposed off in open dumps to be acted upon by the elements of the weather. Similarly, the by-products of manufacturing are not recycled because of the cost involved. There is also a lack of supervision by government agencies responsible for controlling waste disposal in the environment. Furthermore, Non-mangrove areas have more human activities, which generate more household (organic) waste e.g. kitchen, restaurant and industrial wastes. Leachates from these wastes are carried by flooded water. Calcium, Potassium and Magnesium are products of food industries, which is often found in the municipality than in mangrove forest. Excess phosphorus when carried to aquatic environment result in nutrient enrichment (eutrophication). Calcium is an essential element in living things needed for the healthy growth of teeth and bones. Calcium is the fifth most abundant element in the earth crust (4.1\%). It occurs as limestone (calcium carbonate), gypsum (calcium sulfate), fluorite (calcium fluoride) and apatite (calcium choloro- or fluoro-phospahate) [27]. It is a component of the geochemistry of the earth. The higher amount of sulphate in mangrove soil than in Non-mangrove soil is as a result of high amount of sulphur bacteria communities such as sulphur-oxidizing and sulphur-reducing bacteria [28]. These bacteria carry out decomposition of mangrove litter.

\subsection{Nutrient and Heavy Metal Relationship in Mangrove and Non-mangrove Forests}

The positive linear relationship of heavy metals and nutrient elements in mangrove and Non-mangrove soils is as a result of natural and anthropogenic factors. The earth crust is made up of minerals, which is often at non-toxic background level. Especially the soils of the Niger Delta are formed from sedimentary rocks [29, 30] through weathering process caused by physical (soil tillage during farming, breaking of rocks to make concrete), chemical (dissolution, solution and distillation activities of rainfall and sunlight) and biological (burrowing activities of rodents, bush burning, deforestation etc) processes. However, in recent times industrialization of cities and the establishment of oil and gas industries in coastal towns [28] have led to the migration of people leading to increase in population with a resultant increase in waste generation. These anthropogenic activities have led to the increase in the background level of metal and nutrient elements in both mangrove and Nonmangrove areas. Municipal areas have more human presence than mangrove forests, and therefore have more waste disposal points than mangrove forests. Waste generated by humans contains both organic and inorganic products that lead to the formation of metallic compounds that migrate from upstream to downstream via surface or sub surface water. The geography of the landscape of the Niger Delta, which slopes seaward [31] also facilitate the migration of waste water into the river.

\section{Conclusion}

Mangrove and Non-mangrove forest are recipients of heavy metal and nutrient element as a result of increased human activities caused by industrialization, urbanization, oil and gas exploration and mining. Proliferation of industries leads to the migration of people into municipal areas resulting in increased waste generation. However, Nonmangrove areas such as municipal areas produce more waste, and therefore have higher concentration of heavy metals and nutrients. During rainfall these metals migrate via flood water down slope into the mangrove wetlands. High heavy metal is harmful to health when it enters the food chain. Increased heavy metal concentration in mangrove forest can contaminate aquatic organisms (fishes, crabs, and periwinkles) and when consumed can lead to public health problems through biomagnifications and bioaccumulation.

\section{Recommendations}

Waste can be inimical to public health when improperly disposed in mangrove and municipal areas. Therefore, municipal waste should be well taken care of in terms of the disposal technique applied such as land fill. This is possible if the waste is non-toxic and has high biodegradability. Municipal waste is more often large in volume, and to reduce the density before final disposal in land fill, a controlled incineration can be done if it has low moisture content and high combustibility. However, if the component of the waste is toxic it can be disposed via deep sea burial to prevent the leaching of its components into ground water, and the erosion of its content into wet land locations such as mangrove forest.

\section{Conflict of Interest}

The author declares that there is no conflict of interest.

\section{Acknowledgements}

The author wish to thank Project students of U 2013 in the Department of Animal and Environmental Biology, University of Port Hacrourt for assistance in sample collection. 


\section{References}

[1] O. Oresanya, Waste Control Measures and Responsibility of a Waste Manager within the Framework of Recent Management Methods and Development in Municipal and Industrial Wastes. Paper presented at the Workshop on Effective Waste Management in Nigeria Organized by the Nigerian Society of Engineers, Lagos. (1998).

[2] N. C. Duke, Mangrove floristics and Biogeography. In "In tropical Mangrove Ecosytems" (A. I Robertson and D. M Alongi, eds). American Geographical Union, Washington DC., USA. (1992) 63-100.

[3] N. C. Duke, M. C. Ball, J. C. Ellison, Factors influencing biodiversity and distributional gradients in man mangroves. Global Ecol. and Biogeo. Letters 7 (1998) 24-47.

[4] D. Rabinowitz, Mortality and initial propagule size in mangrove seedlings in Panama, The J. of Ecol. (1978) 45-51.

[5] L. D. Lacerda, C. E. V. Carlvalho, F. K. Tanizaki, A, R. C. Ovalle, C. E. Rezende, The biogeochemisty and trace metals distribution of mangrove rhizopheres. Biotropica 25 (1993) 251-256.

[6] K. Kathiresan, B. L. Bingham, Biology of mangrove ecosystems. Adv. in Mar. Biol. 40 (2001) 81-251.

[7] U. L. Kaly, G. Eugelink, A. I. Robertson, Soil conditions in damaged North Queensland mangroves. Estuaries 20 (2) (1997) 291-300.

[8] A. L. Ramanathan, Sediment characteristics of the Pichavarammangrove environment, South east coast of India, Ind. J. Mar. Sci., 26 (1993) 319-322.

[9] K. R. Reddi, N. Jayaraju, I. Sunyakumar, K. Sreenivas, Tidal fluctuation in relation to certain physico-chemical parameters in Swarnamukk river estuary, East coast of India. Ind. J. Mar. Sci., 22 (1993) 232-234.

[10] K. K. Satpathy, Seasonal distribution of nutrients in the coastal waters of Kalpakkam, East coast of India. Ind. J. Mar. Sci., 25 (1996) 221-224.

[11] P. S. Asha, K. Diwakar, Hydrobiology of the inshore waters of Tuticorin in the Gulf. J. Mar. Bio. Ass. India, 49 (2007) 7-11.

[12] S. Zauyah, B. Juliana R. Noorhafizah, C. I. Fauzah, A. B. Rosenami, Concentration and speciation of heavy metals in some cultivated and uncultivated ultisols and inceptisols in Peninsular Malaysia, Super - Soil 3rd Austrlian New Zealand Soils Conference, University of Sydney, Austrlia; (2004).

[13] R. R. Twilley, Coupling of mangroves to the productivity of estuarine and coastal waters. In: Coastal-Offshore Ecosystems Interactions: Lecture Notes on Coastal and Estuarine Studies 22. Berlin: Springer-Verlag. (1988) 155-180.

[14] A. O. Numbere, Municipal solid waste disposal in mangrove forest: environmental implication and management strategies in the Niger Delta, Nigeria. In: Municipal solid waste management. IntechOpen. (2019).

[15] L. D. Lacerda, W. Machdo, M. Moscatheli (2000). Use of mangroves in landfill management. Glomis Electronic Journal 1 (1) 1.

[16] J. F. N. Abowei, F. D. Sikoki, Water Pollution Management and Control, Double Trust Publications Company, Port Harcourt; ISBN: 978-30380-20-16. (2005).

[17] K. G. Boto, Nutrients and mangroves. Pollution in tropical aquatic systems, CRC Press (2018), 137-154.

[18] A. O. Numbere, G. R. Camilo, Effect of pollution and seasonal changes on litter fall and 10 accumulation in mangrove forest (Rhizophora species) of the Niger Delta, Nigeria. J. of 11 Environ. Sci. and Tech., 11 (2) (2018) 86-94.

[19] APHA, Standard Methods for the examination of water and waste water, 19th edition, American Water Works Association water pollution control federation publication, Washington, DC. (1995).

[20] F. S. Watanabe, S. R. Olsen, Test of an Ascobic Acid Method for Determining P in water and NaHCO Extracts from Soils. Soil Sci Amer. Pro. 29 (1965) 77-678.

[21] M. Logan, Biostatistical design and analysis using R: a practical guide. John Wiley and 35 Sons, England (2010).

[22] G. P. Quin, K. J. Keough, Experimental design and data analysis for bioogists. Cambridge University Press, London. (2002).

[23] Development Core Team, (2013) R: A Language and Environment for Statistical Computing. R Foundation for Statistical Computing, Vienna Austria. (Accessed on December 2013)

[24] C. Marchand, E. Lallier-Verges $\backslash$, F. Baltzer, P. Alberic, D. Cossa, P. Baillif, Heavy metals distribution in mangrove sediments along the mobile coastline of French Guiana. Mar. Chem. 98 (1) 1-17.

[25] R. J. Snowden, I. K. E. Ekweozor, The impact of a minor oil spillage in the estuarine Niger Delta. Mar Pollut Bull 18 (1987) 595-599.

[26] G. N. Anaero-Nweke, A. P. Ugbomeh, I. K. E. Ekweozor, M. Moslen, N. Ebere, Heavy 4 Metal Levels in Water, Sediment and Tissues of Sarotherodon melanotheron from the 5 Upper Bonny Estuary, Nigeria and Their Human Health Implications. Int. J. of Mar. Sci. 68 (23) (2018) 186-194.

[27] W. M. Haynes ed., (2015) CRC Handbook of Chemistry and Physics, CRC Press/Taylor and Francis, Boca Raton, FL, 95th Edition.

[28] M. Varon-Lopez, A. C. F. Diaz, C. C. Fasanella, A. Durrer, I. S. Melo, E. E. Kuramae, F. D. Andreote, Sulphur-oxiding and sulphur-reducing communities in Brazilian mangrove sediments. Environmental Microbiology, 16 (3) (2014) 845855.

[29] Shell Petroleum Development Company (SPDC), EIA of Belema gas injection and oil field development project. (1999) 9-10.

[30] A. O. Numbere, The impact of oil and gas exploration: invasive nypa palm species and urbanization on mangroves in the Niger River Delta, Nigeria. In: Makowski, C; Finkl, C. (eds) threats to mangrove forests. Coastal Research Library, 25 (2018) Springer, Cham.

[31] J. E. Damuth, Neogene gravity tectonics and depositional processes on the deep Niger Delta continental margin. Marine and Petroleum Geology, 11 (3) (1994) 320-346. 